No 4077

Studia nad Autorytaryzmem i Totalitaryzmem 43, nr 3

Wrocław 2021

https://doi.org/10.19195/2300-7249.43.3.27

\author{
DOBROSŁAWA ANTONÓW \\ ORCID: 0000-0001-8545-1932 \\ Uniwersytet Wrocławski \\ dobroslawa.antonow@uwr.edu.pl
}

\title{
Podatek od zysków wojennych w polskim systemie danin jako źródło finansowania kosztów wojny polsko-bolszewickiej
}

Słowa kluczowe: podatek, podatek od zysków wojennych, wojna, podatek nadzwyczajny, wojna polsko-bolszewicka, pierwsza wojna światowa, koszty wojny, gospodarka wojenna, wydatki publiczne, odrodzona Polska, okres międzywojenny, podatki w okresie międzywojennym, historia skarbu państwa polskiego, wojna z Sowietami.

\section{TAX ON WAR PROFITS IN THE POLISH LEVY SCHEME AS A SOURCE OF FINANCING THE COSTS OF THE POLISH-SOVIET WAR}

Abstract

The paper draws attention to one of the emergency taxes in the history of the Polish Treasury, i.e. a tax on war profits. It was levied under the Decree of 5 February 1919 on the Establishment of a Tax on War Profits. This levy introduced a concept which was developed in Europe and built on the First World War experience. In the reborn Poland, the tax was supposed to have two functions: fiscal as a source of financing the extraordinary expenditure arising from the war against the Soviets and a social function - as an additional burden on those taxpayers who were able to accumulate wealth and earn substantial profits as a result of the First World War.

Keywords: tax, tax on war profits, war, emergency tax, Polish-Soviet War, First World War, war costs, war economy, public expenditure, reborn Poland, interwar period, taxes in interwar period, history of the Polish Treasury, war against the Soviets. 


\section{Wprowadzenie}

Okresy szczególne w historii państw świata wywoływało wiele różnych czynników. Znaczne niepokoje społeczne i destabilizacja polityczna, ustrojowa i gospodarcza objawiały się zwłaszcza wtedy, gdy ścierały się mocarstwa, kształtowały się granice państw, tożsamości narodowe i etniczne, ustroje, procesy integracyjne, forsowane były ideologie, w tym autorytaryzm i totalitaryzm, a także gdy poszczególne państwa, regiony lub kontynenty toczyły walkę z tymi zagrożeniami lub ich skutkami. Okresy nadzwyczajne wiązały się też z okolicznościami niezależnymi od człowieka lub zależnymi od niego w mniejszym stopniu, jak klęski żywiołowe i epidemie. Właśnie one, odmienne od tych niezakłóconych nadzwyczajnymi okolicznościami, tworzą dla każdego państwa nie tylko wyzwanie organizacyjne, lecz przede wszystkim nadzwyczajne wyzwania finansowe. Walka o bezpieczeństwo, głębokie przemiany ustrojowe i gospodarcze, migracja, inflacja, zmiana waluty, klęski żywiołowe, epidemie, a zwłaszcza wojny szczególnie wpływają na strukturę wydatków i dochodów państwa. W tym czasie nie tylko rosną sztywne wydatki publiczne, lecz - co ważniejsze - generowane są wydatki nadzwyczajne związane z potrzebą reagowania przez państwo na zaistniałe szczególne okoliczności, to jest służące walce ze skutkami niepożądanych procesów i zjawisk oraz przywróceniu stanu dotychczasowego. Wówczas najczęściej te potrzeby nie znajdują pokrycia we wpływach do budżetu. Typowe dla takich okresów jest więc poszukiwanie dodatkowych źródeł finansowania rosnących wydatków. Głównie są to źródła zewnętrzne (na przykład kredyty), ale równie często oznacza to zwiększanie dotychczasowych podatków lub poszukiwania nowych źródeł opodatkowania i pobór nowych podatków. Takie podatki określane są jako nadzwyczajne. Od podatków zwyczajnych, będących trwałym elementem systemu podatkowego, odróżnia je to, że są wprowadzane jako obciążenie jednorazowe ${ }^{1}$. Zazwyczaj są to podatki o charakterze celowym, co w zamierzeniu ustawodawcy oznacza, że wpływy z ich tytułu mają być przeznaczone na określony, z góry przyjęty cel. Cechą podatków nadzwyczajnych jest też często ich szczególne uzasadnienie, nawiązujące nie tylko do potrzeb fiskalnych, lecz także pozafiskalnych, przede wszystkim społecznych. Nabierają więc cech podatków interwencyjnych (porządkowych) ${ }^{2}$.

${ }^{1}$ M. Kalinowski, Rodzaje podatków i ich klasyfikacja podatkowe oraz systemy podatkowe, [w:] System prawa finansowego, t. 3. Prawo daninowe, red. L. Etel, Warszawa 2010, s. 72; C. Kosikowski, Pojęcie, funkcje, rodzaje dochodów publicznych, [w:] Finanse publiczne i prawo finansowe, red. C. Kosikowski, E. Ruśkowski, Warszawa 2003, s. 470. Dochody — podatki nadzwyczajne odróżniane od zwyczajnych, stałych, i rozumiane jako zmienne znane są w historii skarbowości od początku jej istnienia, bo już w państwach starożytnych; na ten temat S. Owsiak, $Z$ historii daniny publicznej, „Zeszyty Naukowe Akademii Ekonomicznej w Krakowie” 2000, nr 542, s. 7.

2 R. Mastalski, Prawo podatkowe, Warszawa 2018, s. 358. 
Efektem doświadczeń państw świata w poszukiwaniu źródeł finansowania potrzeb w czasie nadzwyczajnym, jakim jest wojna, jest koncepcja podatku od zysków wojennych. Taka nadzwyczajna danina publiczna znana jest również w historii polskiej skarbowości — na przykład podatek od zysków wojennych pobierany w latach 1919-1920, czyli w trakcie wojny odrodzonej Polski z bolszewikami.

\section{Koncepcja podatku od zysków wojennych}

Punktem wyjścia koncepcji podatku od zysków wojennych było założenie o odmiennych warunkach wywołanych wojną, które zrodziły nowe zagadnienia w zakresie nauk ekonomiczno-skarbowych. To zaś stało się podstawą nowej nauki — skarbowości wojennej ${ }^{3}$. Mimo że koncepcja tworzenia teorii w tym zakresie była dyskusyjna, wątpliwości nie budził wpływ wojny na skarbowość oraz nadzwyczajny charakter okoliczności z tym związanych. Wojnę w tym kontekście oceniano jako zjawisko nienormalne, przejściowe, patologiczne ${ }^{4}$. Na kanwie doświadczeń pierwszej wojny światowej zauważono, że nadzwyczajny charakter takiego czasu wywoływał wpływ na sytuację finansową państwa, gdyż jak zauważano: „niepodobna liczyć na regularne opłacanie podatków, wskutek zaś tego, państwa będą zmuszone drogą nadzwyczajną szukać środków nie tylko na pokrycie rozchodów wojennych, lecz i na zaspokojenie zwykłych potrzeb"5. Zagadnienie skarbowe wymagające rozwiązania w czasie wojny definiowano następująco: „trzeba znaleźć środki dla pokrycia wydatków wskutek wojny, dla amortyzacji długów wojennych, przestrzegając jednocześnie zasadę sprawiedliwości i słuszności opodatkowania”6. W tym szczególnym czasie na znaczeniu zyskują podatki nadzwyczajne, do których należy właśnie podatek od zysków wojennych. Wyjątkowego znaczenia nabiera też zasada możności płatniczej (to jest zdolności płatniczej), a obowiązek ponoszenia ciężarów podatkowych dotyczy zwłaszcza tych, którzy ,podczas wojny poprawili swe położenie materjalne ze szkodą innych, do tych wszystkich, którzy nie ponieśli ofiar, a odwrotnie zyskali"7. Poza oczywistymi celami fiskalnymi w zwiększeniu spektrum ciężarów publicznych upatrywano też realizacji celów dodatkowych określonych jako ,socjalno-polityczne", rozumianych w ten sposób, że

${ }^{3}$ E. Strasburger, Zagadnienie skarbowo-ekonomiczne na tle wojny, Warszawa 1920, s. 12. Teoria gospodarczo-wojenna zrodziła się w Niemczech, głównie w kontekście doświadczeń pierwszej wojny światowej. Jednym z jej głównych twórców był Johann Plenge, zob. Der Krieg und die Volkswirtschaft, Münster 1915. Na temat badań nad koncepcją teorii gospodarczo-wojennej więcej E. Strasburger, op. cit., s. 12 n.

${ }^{4}$ E. Strasburger, op. cit., oraz bogata literatura tam powołana.

5 J. Błoch, Przyszła wojna pod względem technicznym, ekonomicznym i politycznym, Warszawa 1900, s. 150, cyt. za: E. Strasburger, op. cit., s. 14.

${ }^{6}$ E. Strasburger, op. cit., s. 15.

7 Ibidem, s. 35. 
dzięki roztropnej polityce podatkowej mogą być wyrównane sposobem sztucznym nierówności majątkowe, które się wytworzyły wśród różnych warstw społecznych historycznie, lub też wskutek koniunktury gospodarczej [...] drogą wysokiego podatku dochodowego i od zysków wojennych państwo może odebrać część zysków, które powstały dzięki koniunkturze i zbiegowi okoliczności ${ }^{8}$.

Podatek od zysków wojennych określano w doktrynie jako „wytwór wojny w dziedzinie podatków", a jego celem było ,uchwycenie na rzecz państwa zysków nadmiernych, powstałych podczas trwania wojny"10. Zysk wojenny zaś to nadwyżka dochodów osób i przedsiębiorstw powstała podczas wojny; przyrównywano go do ,jakby renty” wojennej, gdyż narodził się w wyniku okoliczności niezależnych od tego, kto go osiąga. W warunkach wojennych kształtował się przede wszystkim w związku z rosnącymi dostawami dla armii, a następnie (ze względu na niedostosowanie podaży do popytu) również w związku $\mathrm{z}$ dostawami pierwszej potrzeby ${ }^{11}$. Podatek ten postrzegany był także jako instrument zapobiegania tworzeniu się tak zwanych fortun wojennych, odbieranych przez społeczeństwo negatywnie ${ }^{12}$.

\section{Potrzeby fiskalne odradzającego się państwa polskiego w okresie wojny z bolszewikami}

Odzyskanie niepodległości przez Polskę wiązało się z wieloma wyzwaniami, nie tylko politycznymi, prawnymi i organizacyjnymi, lecz także gospodarczymi $^{13}$. W literaturze zauważa się, że początki gospodarki odrodzonej Polski ukształtował uprzedni - długo utrzymujący się - stan gospodarki wojennej ${ }^{14}$.

8 Ibidem, s. 36.

9 Ibidem, s. 37.

10 Ibidem.

11 Ibidem, s. 38.

12 K. Szlichciński, Polityka finansowa państwa w warunkach wojennych, „Acta Universitatis Lodziensis. Folia Oeconomica" 1993, nr 126, s. 50.

${ }^{13} \mathrm{Na}$ ten temat zob. M. Górski, Niepodległość kosztuje. Początki podatku dochodowego w II Rzeczypospolitej, „Miscellanea Historico-Iuridica” 17, 2018, z. 1, s. 93 n., DOI: 10.15290/mhi. 2018.17.01.06; A. Zawojska, Podłoża stosunków gospodarczych Polski z zagranica w okresie międzywojennym - nacjonalizm gospodarczy, protekcjonizm i liberalizm, [w:] Polska we współczesnych międzynarodowych stosunkach gospodarczych, red. E. Kacperska, Warszawa 2019, s. 9-30; S. Kwiecień, Ewolucja rozwiąań prawnych w sferze podatku przemysłowego jako element polityki podatkowej państwa polskiego w okresie międzywojennym, „Forum Prawnicze” 2020, nr 3 (59), s. 95-109.

14 A. Podolska-Meducka, Problemy gospodarcze Polski w okresie wojny z bolszewikami zarys problematyki, „Zeszyty Naukowe Uniwersytet Ekonomiczny w Krakowie” 2019, nr 6 (984), s. 26. Na potrzeby wydatkowe odrodzonego państwa oraz system daninowy II RP (jako szczególnie wyróżniający się okres w historii polskiej skarbowości, mający wpływ na współczesny system podatkowy) wskazuje S. Owsiak, op. cit., s. 12. 
Dodatkowym wyzwaniem i ogromnym wysiłkiem finansowym dla odrodzonego państwa polskiego była kolejna wojna — z bolszewikami w latach 1919-1921. Odrodzenie państwa oznaczające wyjście z gospodarki wojennej, dające nadzieję na budowanie gospodarki rynkowej, dość szybko przeszło w kolejny okres gospodarki wojennej ${ }^{15}$. Czas zaraz po odzyskaniu niepodległości jest określany w historii polskiej skarbowości jako „okres nadzwyczajnych wpływów”" ${ }^{\text {. Oprócz }}$ zasadniczych działań polegających na budowie systemu podatkowego i unifikacji prawodawstwa państw zaborczych obowiązującego na poszczególnych terenach odrodzonej Polski ${ }^{17}$ podejmowano wówczas też działania doraźne w celu maksymalizacji dochodów budżetowych, między innymi przez wprowadzanie nowych, nadzwyczajnych danin w celu pokrycia wydatków związanych $\mathrm{z}$ odbudową państwa. Taką daniną był przede wszystkim podatek od zysków wojennych ${ }^{18}$.

Okres trudów odbudowy państwa wiązał się z wyraźnie dostrzegalnymi dysproporcjami majątkowymi w społeczeństwie ${ }^{19}$. Te pobudzały w warstwach uboższych potrzebę ich wyrównywania w imię sprawiedliwości społecznej. Miał temu służyć szczególny podatek, zapewniający środki na utrzymanie odradzającego się państwa w realiach gospodarki wojennej, przy jednoczesnym wyrównaniu rachunków społecznych między tymi, którzy podczas wojny utracili, a tymi, którzy zyskali majątek.

\section{Uzasadnienie i regulacje prawne w przedmiocie podatku od zysków wojennych}

Podatek od zysków wojennych wprowadzony został na mocy dekretu w przedmiocie podatku od zysków wojennych z dnia 5 lutego 1919 roku $^{20}$ (dalej: dekret). Miał on moc obowiązującą od dnia ogłoszenia w Dzienniku Praw (art. 66 dekretu) i wprowadził podatek na obszarze ziem polskich byłego zaboru rosyjskiego (art. 1). Był on zmieniany jeden raz w drodze rozporządzenia Rady Obrony Państwa z dnia 18 sierpnia 1920 roku w przedmiocie zmiany terminu płatności

15 Na temat uwarunkowań gospodarczych w Polsce, wojennych wydatków nadzwyczajnych oraz wyzwań związanych z poszukiwaniem środków na ich sfinansowanie w okresie wojny z bolszewikami w latach 1919-1921 więcej A. Podolska-Meducka, op. cit., s. 25-42.

16 C. Brzeziński, Polska gospodarka finansowa, Warszawa 1921, s. 17; na ten temat więcej P. Grata, Kierunki polityki podatkowej państwa Polskiego w roku 1919, „Polityka i Społeczeństwo” 2010, nr 7, s. 49 oraz literatura tam powołana.

$17 \mathrm{Na}$ temat danin publicznych i kształtowania się systemu podatkowego w Polsce międzywojennej więcej między innymi L. Adam, Podatki i opłaty w kapitalizmie, Warszawa 1962, s. 99 n.; R. Mastalski, op. cit., s. 361 n.

18 P. Grata, op. cit., s. 50.

19 Na ten temat R. Rybarski, Ciężar podatków w Polsce, Warszawa 1924, s. 11-12.

20 Dz. Praw P. Pol. 1919.12.136. 
podatku od zysków wojennych na obszarze byłego zaboru rosyjskiego ${ }^{21}$. Rozporządzenie to zmieniało jedynie termin płatności podatku, a więc pozostawało bez wpływu na charakter prawny i konstrukcję podatku ${ }^{22}$.

Dekret obowiązywał do 31 grudnia 1920 roku. Był on regulacją kompleksową i zawierał przepisy określające konstrukcję prawną podatku od zysków wojennych ${ }^{23}$, miejsce opodatkowania i organy wymiarowe (art. 25-30), postępowanie (art. 31-38), instytucję nakazu płatniczego (art. 39), odwołanie (art. 40-43), terminy płatności (art. 44-45), nadzwyczajne ulgi (to jest zwolnienie, zniżenie lub darowanie) (art. 46), a także postanowienia karne (art. 47-56), zabezpieczenie podatku (art. 57-65) i postanowienia końcowe (art. 66-68). Na szczególną uwagę zasługuje, że prawodawca uregulował szczegółowo kwestie proceduralne, to jest procedury szczególne związane z poborem podatku oraz mechanizmy przymusowej egzekucji podatku. Te dość wyraźnie realizowały podłoże ideologiczne podatku wojennego i odpowiadały oczekiwaniom społecznym z tym związanym. Jako uzasadnienie wprowadzenia podatku od zysków wojennych Ministerstwo Skarbu wskazało:

Potrzeba zasilenia Skarbu Państwa nowemi wpływami pieniężnymi dla uzyskania środków na pokrycie stale wzrastających wydatków Państwa oraz wzgląd na jednomyślną opinię społeczeństwa, domagającą się opodatkowania nadzwyczajnych zysków lub dochodów, osiągniętych w latach wojennych, skłoniły Rząd do wprowadzenia Dekretem Naczelnika Państwa podatku od zysków wojennych. Wprowadzenie tego podatku przedstawia się, bez potrzeby bliższego uzasadnienia, jako najbardziej usprawiedliwione, gdyż słuszność wymaga, aby ci, którzy wskutek wojny osiągnęli nadzwyczajne zyski lub dochody, przyczynili się w odpowiednio wyższym stosunku, niż inni współobywatele do pokrycia wzmożonych wskutek wojny potrzeb Państwa 24 .

21 Dz.U.1920.81.542.

22 Do dekretu zostały wydane rozporządzenia wykonawcze: rozporządzenie Ministra Skarbu z dnia 12 maja 1919 r. w wykonaniu dekretu z dnia 5 lutego 1919, Dz.Pr. Nr 12, poz. 136, w przedmiocie wprowadzenia podatku od zysków wojennych, Dz. Praw P. Pol. 1919.46.320 (rozporządzenie to miało charakter stricte wykonawczy i zawierało wyjaśnienia i szczegółowe regulacje wykonawcze do całości postanowień dekretu); dwa pozostałe rozporządzenia dotyczyły rozciągnięcia działania dekretu na dochody osiągnięte w latach 1919-1920, a następnie ograniczenia tego rozciągnięcia do roku 1919: rozporządzenie z dnia 12 maja 1920 r. o rozciągnięciu na obszarze b. zaboru rosyjskiego działania dekretu w przedmiocie wprowadzenia podatku od zysków wojennych z dnia 5 lutego 1919 r. (Dz.Pr. Nr 12, poz. 136) na zyski, względnie dochody osiągnięte w latach 1919 i 1920, Dz.U. 1920.50.307; oraz rozporządzenie Ministra Skarbu z dnia 11 marca 1921 r. w przedmiocie ograniczenia mocy obowiązującej rozporządzenia z dnia 12 maja 1920 r. (Dz.U. R.P. nr 50 z r. 1920, poz. 307) o rozciągnięciu na obszarze b. zaboru rosyjskiego działania dekretu w przedmiocie wprowadzenia podatku od zysków wojennych z dnia 5 lutego 1919 r. (Dz.Pr. Nr 12 z r. 1919 poz. 136) na zyski względnie dochody osiągnięte w latach 1919 i 1920, Dz.U.1921.31.187

${ }^{23}$ Obowiązek podatkowy — podmiot opodatkowania: art. 2, przedmiot opodatkowania: art. 3-9, uwolnienia podatkowe: art. 10, podstawa opodatkowania: art. 11-19, stopa podatku: art. 20-24.

24 E. Strasburger, Ustrój skarbowy Rzeczypospolitej Polskiej, Warszawa 1922, s. 126. 
Uzasadnienie to wprost kreśli dwa cele podatku wojennego w Polsce w analizowanym okresie. Cel fiskalny - zapewnienie pokrycia rosnących wydatków publicznych związanych z odbudową strat po pierwszej wojnie światowej. Cel drugi, pozafiskalny, nawiązywał do społecznej potrzeby wyrównania dysproporcji społecznych i ekonomicznych spowodowanych pierwszą wojną światową. Z tym jednak, że oczekiwanie społeczne koncentrowało się bardziej na pozbawieniu majątków tych, którzy w czasie wojny go pomnożyli, niż wzbogaceniu zubożonych. Trudno przesądzić, który z celów był ważniejszy. Przypuszczać można, że dla państwa ten pierwszy — cel fiskalny, dla społeczeństwa zaś cel drugi.

\section{Konstrukcja podatku od zysków wojennych}

Katalog podmiotów, na których ciążył obowiązek podatkowy (podatników), wskazywał art. 2 dekretu. Zgodnie z tym przepisem podatkowi podlegały: towarzystwa, spółki akcyjne i inne z ograniczoną odpowiedzialnością, instytucje kredytowe, wszelkie towarzystwa i instytucje, które w myśl obowiązujących przepisów były zobowiązane do publicznego składania rachunków (bez względu na to, czy opłacały podatek przemysłowy) oraz wszystkie inne osoby prawne i osoby fizyczne oraz spadki wakujące. Zakres podmiotowy był więc bardzo szeroki i obejmował wszelkie jednostki życia społecznego znane ówczesnemu systemowi prawnemu.

Przedmiot opodatkowania został określony w art. 3-9 dekretu odrębnie dla każdej z wymienionych kategorii podatników. Generalnie przedmiot podatku był (zgodnie z nazwą tej daniny) powiązany z zyskiem bądź z dochodem podatnika. Odnośnie do towarzystw obowiązanych do publicznego składania rachunków był to zysk przedsiębiorstwa, w wypadku innych osób prawnych i osób fizycznych był to zysk, względnie dochód, a spadków wakujących była to nadwyżka dochodu. Zasadnicze znaczenie dla konstrukcji tego podatku miał mechanizm ustalenia przedmiotowego zysku lub dochodu. W tym zakresie ustawodawca posłużył się kategoriami pojęciowymi: rok/lata operacyjne w czasie pokoju i rok/lata wojenne. Mechanizm ustalenia zysku (ewentualnie dochodu) do opodatkowania opierał się na porównaniu zysku (dochodu) w operacyjnych latach wojennych (od 1 sierpnia 1914 roku do końca 1918) do zysku w ostatnich trzech latach operacyjnych w czasie pokoju. Opodatkowaniu podlegała nadwyżka zysku z lat wojennych nad zyskiem z lat pokojowych. Przepisy szczegółowe regulowały dodatkowo kwestie złożone, na przykład gdy przedsiębiorstwo nie działało w całym okresie lat wojennych lub gdy w latach pokojowych nie było w ogóle zysku. W odniesieniu do dochodu obowiązywał podobny mechanizm, przy czym punkt odniesienia tworzył dochód podatnika lub spadku wakującego w roku 1913, ewentualnie na żądanie podatnika przeciętny dochód z ostatnich trzech lat pokojowych.

Dekret przewidywał pewne uwolnienia od podatku (art. 10). Obejmowały one między innymi dochody z nieruchomości państwowych lub dochody z dzia- 
łalności skierowanej na ogólnie pożyteczne cele. Uwolnienie od podatku wynikać więc mogło jedynie z przesłanek działalności lub przeznaczenie zysków (dochodów) w sposób zgodny z oczekiwaniami społecznymi.

Ze względu na wyraźnie zdefiniowany kontekst społeczny podatku jako formy obciążenia zysków (dochodów) wykreowanych w związku z wojną (w wyniku okoliczności społecznych i gospodarczych nadzwyczajnego czasu, jakim jest wojna), z opodatkowania wyłączone zostały zyski nadzwyczajne i jednorazowe (to jest niezależne od koniunktury wojennej ${ }^{25}$ ), takie jak wygrane losowe i loteryjne, spadki, wypłaty z ubezpieczenia czy darowizny (art. 14 dekretu), a także zyski ze sprzedaży przedmiotów majątkowych, ale tylko wówczas, gdy sprzedaż ta nie następowała $\mathrm{w}$ wykonywaniu zajęcia zawodowego lub interesu spekulacyjnego (art. 15 dekretu).

Stawka podatku miała charakter procentowy, progresywny (od nadwyżki wyrażonej $\mathrm{w}$ stosunku procentowym do kapitału zakładowego ${ }^{26}$ ) w przedziale od $10 \%$ do $60 \%$ dla towarzystw sprawozdawczych (art. 20 dekretu), a dla towarzystw zagranicznych aż do $65 \%$ (art. 21 dekretu). Dla wszystkich innych podmiotów stawka wynosiła od 5\% do 70\% (art. 22 dekretu). Zauważano, że określenie nadwyżki w stosunku do kapitału zakładowego chroniło przedsiębiorstwa o znacznym kapitale zakładowym od nadmiernych podatków. W wypadku zaś towarzystw zagranicznych rentowność ta nie była uwzględniana, lecz jedynie absolutna wysokość nadwyżki, co oznaczało, że towarzystwa zagraniczne były obciążane podatkiem wyższym niż krajowe ${ }^{27}$. W ogólnym jednak rozrachunku podatek ten był daniną dotkliwą fiskalnie, gdyż osiągał nawet wysokość $70 \%$.

Dekret przewidywał również instytucję zwyżki podatkowej. Na podstawie art. 14, gdy nadwyżka dochodów osób fizycznych w całości lub w części pochodziła $\mathrm{z}$ dostaw dla wojsk lub z pośrednictwa przy tych dostawach, lub innych podobnych przedsiębiorstwach związanych z gospodarkę wojenną, podatek był zwiększany o $20 \%$.

Z punktu widzenia istoty podatku od zysków wojennych, jego uzasadnienia i kontekstu społecznego szczególnie interesujące są rozwiązania dotyczące procedury jego poboru. Na podatników przerzucony został bowiem ciężar związany $\mathrm{z}$ ujawnieniem osiągniętych zysków podlegających opodatkowaniu w terminie wskazanym przez władze w obwieszczeniu publicznym (art. 31 dekretu). Jeśli nie dopełniono tego obowiązku w odpowiedzi na wezwanie publiczne, podatek był wymierzany przez organ podatkowy na podstawie jego szacunków. Oceniano wówczas, że takie właśnie szacowanie z urzędu stosowane było w większości ${ }^{28}$.

\footnotetext{
25 Ibidem, s. 128.

26 Ibidem.

27 Ibidem.

28 Ibidem, s. 130.
} 


\section{Efektywność podatku od zysków wojennych}

W odniesieniu do samej koncepcji podatku od zysków wojennych w ówczesnej literaturze podnoszono, że co do zasady ,państwo jest uprawnione do amputacji nadmiernych zysków, wytworzonych podczas wojny" ${ }^{29}$. Jednocześnie jednak zauważano trudności z egzekwowaniem tego podatku, głównie przez wzgląd na wahanie walutowe, co często zysk czyniło pozornym. W praktyce zdarzało się więc, że bezkrytyczne stosowanie ustawy prowadziło do obciążenia podatników, którzy w istocie nie wykazywali zysków w rozumieniu dekretu, lecz wręcz przeciwnie - ponieśli straty ${ }^{30}$. W związku z tym koncepcja podatku od zysków wojennych w świetle dekretu była „martwą literą [...] akademicką próbą rozwiązania problemu skarbowego bez praktycznych rezultatów" ${ }^{31}$. Okoliczności szczególne, to jest wahania walutowe, niewątpliwie były problemem typowym tego momentu historii polskiej państwowości. Praktyka jednak wskazywała na jeszcze inne, nie mniej istotne problemy, które dowodziły szkodliwości przyjętej koncepcji podatku od zysków wojennych. Centralny Związek Polskiego Przemysłu, Górnictwa, Handlu i Finansów w dniu 20 września 1920 roku złożył Ministrowi Skarbu memoriał, który dotyczył doświadczeń, ryzyk i postulatów ${ }^{32}$ zwią- $^{-}$ zanych z tym podatkiem. Odwołano się w nim do memoriału złożonego w dniu 15 listopada 1919 roku, w którym wyrażono „obawy co do wysoce szkodliwych skutków gospodarczych, jakie może sprowadzić wymiar podatku od zysków wojennych" ${ }^{33}$. Dalej stwierdzono, że „rzeczywistość przeszła przewidywania najbardziej pesymistyczne. Zadanie dokonania wymiaru tego podatku w ogóle bardzo trudne, okazało się dla naszej administracji skarbowej ponad siły" ${ }^{34}$. Wskazano też na towarzyszące poborowi tego podatku trudności, błędy, a wręcz naruszenia prawa. W związku z tym podatek ten określono „,nową plagą wojenną". Podniesiono zmianę realiów gospodarczych i przeobrażenia walutowe, które były przeszkodą w realnej ocenie zysków okresu wojennego. Zauważono jednak przede wszystkim, że „urzędy skarbowe oceniają stosunki przeszłości według norm chwili obecnej, że nie umieją zachować perspektywy czasu, ulegają sugestii chwili bieżącej i widzą stosunki lat minionych przez pryzmat teraźniejszości”"35. Tak jak motywy i uzasadnienie wprowadzenia podatku nawiązywały do poczucia sprawiedliwości społecznej, tak też czynnik społeczny wskazany został jako

29 Ibidem, s. 131-132.

30 Ibidem, s. 132.

31 Ibidem.

32 Treść memoriału zreferowana została na łamach „Przeglądu Gospodarczego” 1920, z. 14 (15.10.1920), s. 8-9.

33 Ibidem.

34 Ibidem.

35 Ibidem. 
jedno ze źródeł problemów związanych z jego poborem i generalnych zagrożeń odnośnie do zachowania źródła opodatkowania. Zauważono, że

autorytet bezwzględny posiadają w urzędach skarbowych t. zw. informatorzy, czyli mężowie zaufania, istotni sprawcy owych sum milionowych, które wypadnie albo umorzyć, albo wyegzekwować za bardzo drogą cenę zniszczenia wielu przedsiębiorstw oraz zachowania w społeczeństwie wiary w celowość jakichkolwiek przedsięwzięć gospodarczych, dopóki stosunki podatkowe nie ulegną zmianie ${ }^{36}$.

Stwierdzano, że następcze egzekwowanie zysków zgromadzonych w innych realiach pozbawiało podatników możliwości dalszego prowadzenia działalności i zarobkowania, co finalnie wiele przedsiębiorstw doprowadzało do upadku, eliminując istotnych pracodawców oraz podatników na przyszłość. Tak dochodziło więc $\mathrm{w}$ imię poszukiwania nadzwyczajnych źródeł opodatkowania do faktycznego ich unicestwienia. W związku z tym Związek domagał się przede wszystkim między innymi eliminacji supremacji anonimowych informatorów, „których współpraca wprowadza metodę konspiracji i tajemniczości tam, gdzie wszystko odbywać się powinno na podstawie zupełnej jawności i jasności stosunków"37, a także by przepisy dotyczące zabezpieczenia podatku nie paraliżowały normalnego trybu działania przedsiębiorstwa, a egzekucja podatku była wstrzymywana w przypadku uzasadnionych obaw niemożności zapłacenia podatku w terminie i jeżeli egzekucja mogłaby spowodować ruinę podatnika ${ }^{38}$.

\section{Podsumowanie}

Przypomniany w niniejszym artykule podatek od zysków wojennych pobierany $\mathrm{w}$ Polsce $\mathrm{w}$ okresie wojny $\mathrm{z}$ bolszewikami jest przykładem realizacji koncepcji znanej i wykorzystywanej na świecie w wielu państwach. Wywodzi się ona z doświadczeń świata, w którym głównym zagrożeniem była wojna - wówczas powszechne narzędzie realizacji celów politycznych. Przytoczony przykład polskich regulacji odnośnie do podatku od zysków wojennych z roku 1919 związany jest $\mathrm{z}$ bardzo szczególnym momentem $\mathrm{w}$ historii Polski (pierwsza wojna światowa, odbudowa polityczna, prawna i gospodarcza odrodzonej Polski i kolejnej wojny - tym razem z bolszewikami). W ówczesnej rzeczywistości zyski zgromadzone przez niektórych podczas jednej wojny miały być źródłem pokrycia nadzwyczajnych wydatków państwa wynikających z rzeczywistości powojennej i kształtującej się nowej — kolejny raz gospodarki wojennej. Zasadniczym celem podatku od zysków wojennych był cel fiskalny. Co jednak znamienne, na równi z tym celem podatek realizować miał cel społeczno-porządkowy, pożądany
36 Ibidem.
37 Ibidem.
38 Ibidem. 
społecznie jako narzędzie pozbawienia uprzywilejowanej sytuacji majątkowej tych, którym okoliczności pierwszej wojny światowej pozwoliły na pomnożenie majątku. Ów element porządkujący stał się bardzo wyraźny w koncepcji normatywnej, a zwłaszcza w praktyce jego poboru. Ten nadzwyczajny podatek wiązał się bowiem $\mathrm{z}$ równie nadzwyczajnymi metodami jego poboru, $\mathrm{z}$ udziałem informatorów społecznych włącznie. Najważniejsze wnioski, jakich dostarcza, to doświadczenie polskiej skarbowości, dotyczą przede wszystkim dwóch kwestii: zgubnego wpływu emocji społecznych na standardy związane z poborem podatku od zysków wojennych (i wszelkich podatków w ogóle) oraz tego, że konstrukcje i zasady poboru nadzwyczajnych podatków w czasach wyjątkowych i tym samym przejściowych nie mogą być kreowane ze szkodą dla okresów przyszłych - zwyczajnych. W obliczu potrzeb nadzwyczajnych pomijane nie mogą być zwyczajne (wynikające ze standardów systemu podatkowego) zasady poboru podatków. Czujności i ostrożności wymaga również sytuacja, gdy obok (lub w miejsce) władztwa daninowego państwa jako podstawy poboru podatków wkracza społeczne oczekiwanie sprawiedliwości.

\section{Bibliografia}

Adam L., Podatki i opłaty w kapitalizmie, Warszawa 1962.

Błoch J., Przyszła wojna pod względem technicznym, ekonomicznym i politycznym, Warszawa 1900. Brzeziński C., Polska gospodarka finansowa, Warszawa 1921.

Górski M., Niepodległość kosztuje. Początki podatku dochodowego w II Rzeczypospolitej, „Miscellanea Historico-Iuridica” 17, 2018, z. 1, DOI: 10.15290/mhi.2018.17.01.06.

Grata P., Kierunki polityki podatkowej państwa Polskiego w roku 1919, „Polityka i Społeczeństwo” 2010, nr 7.

Kalinowski M., Rodzaje podatków i ich klasyfikacja podatkowe oraz systemy podatkowe, [w:] System prawa finansowego, t. 3. Prawo daninowe, red. L. Etel, Warszawa 2010.

Kwiecień S., Ewolucja rozwiązań prawnych w sferze podatku przemystowego jako element polityki podatkowej państwa polskiego w okresie międzywojennym, „Forum Prawnicze” 2020, nr 3 (59).

Kosikowski C., Pojęcie, funkcje, rodzaje dochodów publicznych, [w:] Finanse publiczne i prawo finansowe, red. C. Kosikowski, E. Ruśkowski, Warszawa 2003.

Mastalski R., Prawo podatkowe, Warszawa 2018.

Memoriał Centralnego Związku Polskiego Przemysłu, Górnictwa, Handlu i Finansów z dnia 20 września 1920 r., „Przegląd Gospodarczy” 1920, z. 14.

Owsiak S., Z historii daniny publicznej, „Zeszyty Naukowe Akademii Ekonomicznej w Krakowie” 2000, nr 542.

Podolska-Meducka A., Problemy gospodarcze Polski w okresie wojny z bolszewikami - zarys problematyki, „Zeszyty Naukowe Uniwersytet Ekonomiczny w Krakowie” 2019, nr 6 (984).

Plenge J., Der Krieg und die Volkswirtschaft, Münster 1915.

Rybarski R., Ciężar podatków w Polsce, Warszawa 1924.

Strasburger E., Ustrój skarbowy Rzeczypospolitej Polskiej, Warszawa 1922.

Strasburger E., Zagadnienie skarbowo-ekonomiczne na tle wojny, Warszawa 1920. 
Szlichciński K., Polityka finansowa państwa w warunkach wojennych, „Acta Universitatis Lodziensis, Folia Oeconomica" 1993, nr 126.

Zawojska A., Podłoża stosunków gospodarczych Polski z zagranica w okresie międzywojennym nacjonalizm gospodarczy, protekcjonizm i liberalizm, [w:] Polska we wspótczesnych międzynarodowych stosunkach gospodarczych, red. E. Kacperska, Warszawa 2019.

\section{Akty prawne}

Dekret w przedmiocie podatku od zysków wojennych z dnia 5 lutego 1919 r., Dz. Praw. P. Pol. 1919.12.136.

Rozporządzenie Ministra Skarbu z dnia 12 maja 1919 r. w wykonaniu dekretu z dnia 5 lutego 1919 (Dz.Pr. Nr 12, poz. 136) w przedmiocie wprowadzenia podatku od zysków wojennych, Dz. Praw P. Pol. 1919.46.320.

Rozporządzenie z dnia 12 maja 1920 r. o rozciągnięciu na obszarze b. zaboru rosyjskiego działania dekretu w przedmiecie wprowadzenia podatku od zysków wojennych z dnia 5 lutego $1919 \mathrm{r}$. (Dz.Pr. Nr 12, poz. 136) na zyski względnie dochody osiągnięte w latach 1919 i 1920, Dz.U. 1920.50 .307

Rozporządzenia Rady Obrony Państwa z dnia 18 sierpnia 1920 r. w przedmiocie zmiany terminu płatności podatku od zysków wojennych na obszarze b. zaboru rosyjskiego, Dz.U.1920.81.542.

Rozporządzenie Ministra Skarbu z dnia 11 marca 1921 r. w przedmiocie ograniczenia mocy obowiązującej rozporządzenia z dnia 12 maja 1920 r. (Dz.U. R.P. nr 50 z r. 1920, poz. 307) o rozciągnięciu na obszarze $b$. zaboru rosyjskiego działania dekretu w przedmiocie wprowadzenia podatku od zysków wojennych z dnia 5 lutego 1919 r. (Dz.Pr. Nr 12 z r. 1919, poz. 136) na zyski względnie dochody osiągnięte w latach 1919 i 1920, Dz.U.1921.31.187. 